
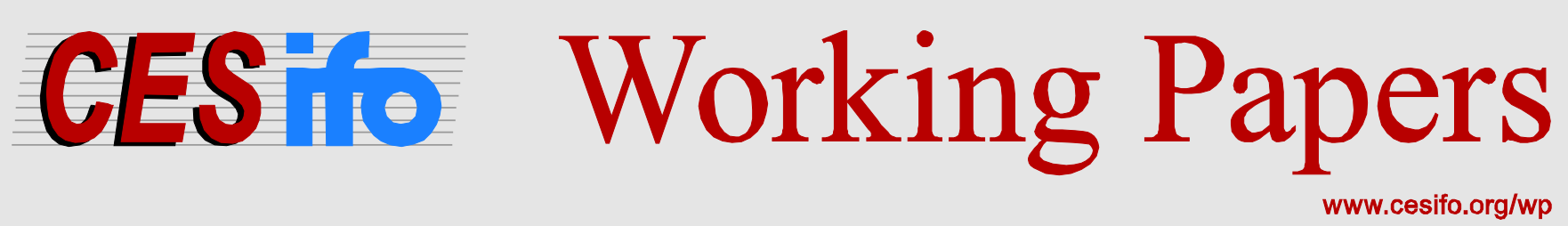

\title{
Spillovers from Systemic Bank Defaults
}

\author{
Mark Mink \\ Jakob de Haan
}

\author{
CESIFO WORKING PAPER NO. 4792 \\ CATEgory 7: MONETARy PoliCy AND InTERnAtional FinANCE \\ MAY 2014
}

An electronic version of the paper may be downloaded

- from the SSRN website:

- from the RePEc website:

- from the CESifo website:

WWW.SSRN.com

www.RePEc.org

www.CESifo-group.org/wp

\section{CESifo}




\title{
Spillovers from Systemic Bank Defaults
}

\begin{abstract}
We examine to what extent banks' stock market values during the 2007-2012 financial crisis were driven by increases in the default risk of banks designated as globally systemically important by the Financial Stability Board. We find that bank market values hardly respond to changes in the default risk of individual systemic banks. Together, however, changes in systemic banks' default risk explain a substantial part of changes in other banks' market values. This result is robust across several sub-samples, using both credit default swap spreads and Moody's expected default frequencies as indicators of default risk.
\end{abstract}

JEL-Code: G010, G150, G210, G280.

Keywords: systemic banks, spillovers, global financial crisis, financial regulation.

\author{
Mark Mink* \\ De Nederlandsche Bank (DNB) \\ P.O. Box 98 \\ The Netherlands - 1000 AB Amsterdam \\ m.mink@dnb.nl
}

\author{
Jakob de Haan \\ De Nederlandsche Bank (DNB) \\ Amsterdam / The Netherlands \\ j.de.haan@dnb.nl
}

\footnotetext{
*corresponding author

Part of this paper was written while this author was visiting the Board of Governors of the Federal Reserve System in Washington, D.C.
}

April 30, 2014 


\section{Introduction}

According to the Financial Stability Board (FSB), "the collapse of Lehman Brothers amply demonstrated that the disorderly failure of a global financial firm has strong spillovers across markets and affects financial stability and national economies around the world. In the months that followed this event, national authorities took unprecedented steps to prevent the systemic collapse of the global financial system. While they were successful in their primary goal, these actions affirmed and sharply increased moral hazard risks in the financial system" (FSB 2010, p.2). This view, which is widely shared amongst policy makers, has inspired a broad range of regulatory initiatives to reduce bank risk-taking and limit the need for bank bailouts in the future ${ }^{1}$ At the same time, and perhaps surprisingly, the unprecedented bailout decisions during the crisis were neither based on a clear understanding of the magnitude of potential spillovers from bank failures, nor on a clear notion of which banks are systemically important.

Consider, for instance, the U.S. government's decision to provide asset guarantees and additional capital to Citigroup in November 2008. As reported by the Office of the Inspector General, responsible for supervising and auditing the operations of the U.S. Federal Government, the premise underlying this intervention was that Citigroup was too systemically significant to be permitted to collapse. Although Citigroup was the second-largest bank in the U.S., the Office concludes that there was surprisingly little information available on the nature and magnitude of any spillover effects its failure could bring about: "the conclusion of the various Government actors that Citigroup had to be saved was strikingly ad hoc. While there was consensus that Citigroup was too systemically significant to be allowed to fail, that consensus appeared to be based as much on gut instinct and fear of the unknown as on objective criteria. As Treasury Secretary Paulson stated on one of the conference calls preceding the rescue, 'If Citi isn't systemic, I don't know what is'." (SIGTARP, 2011 p. 42).

To overcome uncertainty about which banks are systemically important, the Basel Committee on Banking Supervision (BCBS) has recently developed a methodology to assess the systemic importance of individual banks. The first step in this approach is to determine the size of a bank's assets as a percentage of total assets in the banking sector. Next, the bank's

\footnotetext{
${ }^{1}$ For a more sceptical view, we refer to Kaufman (1994), who argues that the academic literature provides "no evidence to support the widely held belief that, even in the absence of deposit insurance, bank contagion is a holocaust that can bring down solvent banks, the financial system, and even the entire macroeconomy in domino fashion." More recently, also De Bandt, Hartmann and Peydró (2010, p. 664) conclude that "the practical and unambiguous identification of concrete contagion cases continues to be a challenge."
} 
scores on four other indicators (interconnectedness, substitutability, cross-jurisdictional activity, and complexity) are taken into account. This results in a ranking of banks which is predominantly driven by bank size (see BCBS, 2011). The BCBS then determines which banks are globally systemically important; for 2011 this was done by using a cut-off point between the 27th and 28th bank. Despite the procedure's merits in determining whether one bank is more systemic than another bank, the question of how systemic these banks are remains unanswered. As a result, there is still considerable uncertainty whether a particular bank is too systemic to be allowed to fail.

To improve our understanding of spillovers from the default of a systemic bank, we focus on the 2007-2012 period to analyse whether changes in the default risk of globally systemically important banks (G-SIBs), designated as such by the FSB, affect the stock market values of other banks. If financial markets expect a G-SIB's default to cause losses for other banks, any increase in a G-SIB's default probability should lead to a decline in other banks' market values. This relationship holds irrespective of the precise spillover channel that is at work, and takes into account that also the anticipation of a G-SIB's potential default can cause spillovers to other banks. Typical event studies examining the impact of large bank defaults cannot allow for such anticipation effects, and due to the rarity of default events have either a smaller or a less homogeneous sample available for their analysis.2

Our regression analysis shows that the market values of banks in the United States and the European Union hardly respond to changes in individual G-SIBs' default risk. This result is in line with Helwege and Zhang (2013), who show that spillovers from financial firm bankruptcies are modest due to, for instance, diversification regulations 3 Despite their small individual impact, however, we find that changes in G-SIBs' default risk together explain a substantial part of changes in bank market values. G-SIBs thus seem systemically important as a group. We discuss that these spillovers could be more modest as well if we underestimate the role of common shocks. Still we find that banks' exposure to common shocks causes their market values to be highly correlated, which Wagner (2010) explains is a source of systemic

\footnotetext{
${ }^{2}$ Some notable examples of event studies analysing the systemicness of individual banks are Brewer III and Jagtiani (2013) and Helwege and Zhang (2013). The first study examines how markets responded to the eight US bank mergers between 1991 and 2004 that caused banks to become bigger than USD 100 billion in assets. The second examines how markets responded to financial firm failures between 1980 and 2010 .

${ }^{3}$ Also Jorion and Zhang (2009) find that the direct impact of a firm's default on its creditors' stock prices is small, especially if this creditor is a financial firm. On average, the abnormal equity return for the 11-day window around the bankruptcy filing is only -1.9 percent.
} 
risk as well. Finally, we show that our results are robust for analysing various sub-samples and for using both credit default swap spreads and Moody's expected default frequencies as indicators of G-SIBs' default risk.

The remainder of this paper is organized as follows. Section 2 introduces our method, Section 3 describes the data used in the empirical analysis, and Section 4 presents our results. The final section concludes.

\section{Method}

\subsection{Modeling spillovers}

There are several channels through which the default of a systemic bank can cause otherwise healthy banks to suffer losses as well. The first channel is the interconnectedness of banks, for instance, through mutual loan and derivative exposures. By defaulting on its obligations to other banks, an insolvent bank can cause these other banks to suffer a loss as well (e.g. Allen and Gale 2000, Freixas, Parigi, and Rochet 2000). Second, Shleifer and Vishny (1992, 2011) discuss how an outflow of funds can force a bank to engage in a fire sale of assets. Especially for illiquid assets such fire sales can depress market prices, and force other banks to write down the value of similar assets on their balance sheets. Third, spillovers can arise from the opacity of banks' balance sheets, which induces uninformed depositors to evaluate the stability of their bank using public signals about the stability of other banks. One bank's default can thereby trigger a run on other banks as well (see Chen 1999).

The magnitude of these spillover effects is hard to evaluate empirically, not least because government interventions render defaults of large, potentially systemic banks a rarely observed phenomenon. Still, even when no systemic bank defaults occur, spillovers can be examined by using changes in the market's perception of these banks' default risk. The presumption is that if financial markets expect a systemic bank's default to cause losses to other banks, an increase in a systemic bank's default probability should lower the market values of the other banks. This relationship between market values and default probabilities should be observed irrespective of the precise spillover channel that is at work. Moreover, it takes into account that the instability of a systemic bank can cause spillovers effects even if the systemic bank does not default. 
To analyze spillovers from bank instability, we model bank market value changes as

$$
y_{n t}=\alpha_{n}+\beta_{n} f_{t}+\sum_{m \neq n} \gamma_{m} p_{m t}+\epsilon_{n t}
$$

where $y_{n t}$ denotes the change in bank $n$ 's stock market value at time $t$, with $n \in(1, N)$ and $t \in(1, T)$. In addition, $f_{t}$ indicates a market factor, and $p_{m t}$ equals the change in the probability that systemic bank $m$ defaults in the future, with $m \in(1, M)$. Idiosyncratic factors driving bank $n$ 's market value are captured by $\epsilon_{n t} 4^{4}$

If there are no spillovers from systemic bank defaults, the model relates the change in bank $n$ 's market value to a constant $\alpha_{n}$ and a market factor $f_{t}$. The coefficient $\beta_{n}$ indicates to what extent the common shocks reflected by this market factor drive changes in the market value of bank $n$, thereby causing market value changes to be correlated amongst banks irrespective of any spillover effects. The coefficient $\gamma_{m}$ indicates to what extent changes in banks' market value are due to changes in systemic bank $m$ 's default risk, and thus accounts for spillover effects. If financial markets expect the default of a systemic bank $m$ to cause losses to other banks, $\gamma_{m}$ will be negative. A positive value for $p_{m}$ then leads markets to attach a higher probability to the risk of a default of $m$, causing market value $y_{n t}$ to decline 5

\subsection{Estimating the model}

In matrix notation, for the th observation, the model in Equation (1) can be written as

$$
y_{t}=\alpha+\beta f_{t}+\Gamma p_{t}+\epsilon_{t},
$$

where $y_{t}$ is an $N \times 1$ vector of changes in banks' market values, $\Gamma$ is the $N \times M$ matrix equal to $\iota_{N} \gamma^{\prime}$ but with elements $\Gamma_{n m}$ replaced by zero if $n=m$, and $\iota_{N}$ is an $N$-vector of ones and $\gamma \equiv\left(\gamma_{1}, \ldots, \gamma_{M}\right)^{\prime}$. To write this model in the usual regression format we rewrite $\Gamma p_{t}$ as $A_{t} \gamma$

\footnotetext{
${ }^{4}$ This model can be interpreted as a variation on event study regressions such as those by Kho, Lee, and Stulz (2000) and Brewer III, Genay, Hunter, and Kaufman (2003). Instead of changes in default probabilities $p_{m t}$, such regressions include dummy variables for days on which $p_{m t}$ is such that bank $m$ actually defaulted. While event studies may find only small effects when the event was anticipated by financial markets, our specification takes anticipation effects into account by including all observed changes in default probabilities rather than just those on bankruptcy dates.

${ }^{5}$ We could allow the impact of changes in the default risk of $m$ to vary across the other $N-1$ banks in the sample. This would, however, increase the number of spillover coefficients to be estimated from $M$ to $M(N-1)$. In our specification the $\gamma_{m}$ coefficients pick up spillovers from banks that are truly systemic, i.e. whose failure would have an impact on multiple banks at the same time.
} 
where $A_{t}=\iota_{n} p_{t}^{\prime}$ with elements $A_{n m t}$ replaced by zero if $n=m$. The entire model is now

$$
y=\left(\iota_{T} \otimes I_{N}\right) \alpha+f \otimes \beta+A \gamma+\epsilon,
$$

with $A$ the $N T \times T$ matrix of all the $A_{t}$ 's stacked on top of each other. Equation (3) is a standard panel regression equation, apart from the unknown factor $f \equiv\left(f_{t}, \ldots, f_{T}\right)^{\prime}$. We define this factor as the coefficient vector from the regression

$$
r=D f+\eta
$$

where $r$ is the residual vector obtained when regressing the market value changes $y$ on the bank-fixed effects $\iota_{T} \otimes I_{N}$ and the default probability changes $A$. The $N T \times T$ matrix $D$ consists of all $N \times T$ matrices $D_{t}$ stacked on top of each other, where $D_{t}$ is a matrix of zeros with ones on the th column.

We can estimate the model in three steps. First, we regress bank market value changes $y_{t}$ on a set of bank-fixed effects $\alpha$ and on changes in default probabilities $p_{t}$. Second, we regress the residuals $r_{t}$ from this regression on a set of period-fixed effects to obtain the market factor $f_{t}$. The market factor thus captures all common variation in the sample that cannot be explained by the changes in default probabilities. Finally, we regress the market value changes on the bank-fixed effects, the changes in default probabilities and the market factor so as to obtain the coefficients of the model in Equation (1). We calculate confidence bounds around these coefficients using a bootstrap procedure. In particular, we resample the residuals within cross-sections and repeat the three estimation steps for 10,000 bootstrap replications, and construct 95-percent confidence intervals using the dispersion of coefficient estimates.

\section{Data}

For the 2007-2012 period, we analyze the 100 largest banks from the United States, the EU15, Iceland, Norway and Switzerland, i.e. banks with the largest stock market capitalization on 1 January 2007 ${ }^{6}$ Table 1 reports the full list of banks, showing that 59 banks in the

\footnotetext{
${ }^{6}$ We select banks that are classified as Bank Holding \& Holding Companies, Commercial Banks, Cooperative Banks, Investment Banks, Real Estate/Mortgage Banks, and Savings Banks. We remove banks for which shares
} 
sample are from countries in the European Union and 41 are from the United States. The largest bank in the sample is Citigroup (U.S.), which at the start of the sample period had a stock market capitalization of USD 274 billion. The smallest bank is Bankinter (Spain), with a market capitalization of only USD 6 billion at the start of the sample.

For each bank in the sample, we calculate changes in market value $y$ as the weekly change in stock market value reported by Thomson Reuters Datastream. We use stock market values in local currencies and express changes therein as a percentage of stock market capitalization at the start of the sample. This way we avoid that our results are driven by only the largest banks in the sample. By focusing on weekly data, our analysis is less sensitive to noise in the market returns and to time lags in the response of market values to changes in default probabilities. In addition, using weekly instead of daily data reduces the issue of non-overlapping trading hours between U.S. and EU stock markets, while retaining a large number of observations for the analysis.

We explain changes in banks' market values from changes in the default risk of banks that either in 2011 or in 2012 were designated by the Financial Stability Board (FSB) as global systemically important financial institution. As explained by FSB (2011), these G-SIBs "are financial institutions whose distress or disorderly failure, because of their size, complexity and systemic interconnectedness, would cause significant disruption to the wider financial system and economic activity. To avoid this outcome, authorities have all too frequently had no choice but to forestall the failure of such institutions through public solvency support." As several banks in the sample went out of business before the FSB published its first G-SIB list in 2011, we designate these banks as G-SIB too if on 1 January 2007 they were larger than State Street, the smallest G-SIB on the FSB list. The resulting 38 G-SIBs are indicated as such in Table 1 ,

We measure changes in a G-SIB's default risk $p$ as the change in its credit default swap (CDS) spread, which we obtain for a 5-year horizon for senior debt from Thomson Reuters Datastream. As CDS spreads equal the percentage premium to be paid for insurance against

were not actively traded during all trading days of January 2007. We also exclude American Express (credit card company), Bayrische Hypo- und Vereinsbank and Bank Austria Creditanstalt (both part of UniCredit), Groupe Bruxelles Lambert (industrial holding company), Mellon Financial Corporation (part of BNY Mellon), GAM (part of Julius Baer), Banca Popolare di Lodi (part of Banco Popolare), TD Ameritrade (online broker), Pargesa (industrial holding company), TD Bank (owned by Canadian holding company), Unionbancal (owned by Japanse holding company), Banca Lombarda e Piemontese (part of UBI Banca) and Mercantile Bankshares (part of PNC Financial Services). 
Table 1: Banks included in the sample

\begin{tabular}{|c|c|c|c|c|c|}
\hline Bank & Country & Value & Bank & Country & Value \\
\hline Citigroup ** & US & 247,717 & Fifth Third Bancorp & US & 21,537 \\
\hline Bank of America ** & US & 222,242 & Bank of Ireland & $\mathrm{IE}$ & 17,628 \\
\hline $\mathrm{HSBC} * *$ & GB & 198,460 & State Street $* *$ & US & 20,832 \\
\hline JP Morgan Chase ** & US & 151,421 & Banco Popular Espanol & ES & 17,749 \\
\hline UBS ** & $\mathrm{CH}$ & 124,416 & National Bank of Greece & GR & 13,638 \\
\hline Royal Bank of Scotland ** & GB & 105,178 & PNC Financial Services & US & 20,598 \\
\hline Wells Fargo $* *$ & US & 113,670 & Raiffeisen International Bank & AT & 11,723 \\
\hline Banco Santander ** & ES & 90,451 & Skandinaviska Enskilda Banken & $\mathrm{SE}$ & 16,122 \\
\hline BNP Paribas ** & $\mathrm{FR}$ & 86,406 & Sallie Mae & US & 22,331 \\
\hline ING $* *$ & NL & 86,373 & Mediobanca & IT & 16,173 \\
\hline Barclays ** & GB & 75,556 & Svenska Handelsbanken & $\mathrm{SE}$ & 17,740 \\
\hline Unicredit $* *$ & IT & 79,725 & Bear Stearns (until 17-03-2008) & US & 16,403 \\
\hline Wachovia (until 29-09-2008) * & US & 87,856 & DnB Nor & NO & 17,374 \\
\hline Banco Bilbao Vizcaya Argentaria ** & ES & 70,540 & Swedbank & $\mathrm{SE}$ & 14,071 \\
\hline Morgan Stanley ** & US & 64,887 & Gruppo Monte dei Paschi di Siena & IT & 14,561 \\
\hline Goldman Sachs $* *$ & US & 66,341 & Banco Espanol de Crédito & ES & 11,936 \\
\hline Credit Suisse $* *$ & $\mathrm{CH}$ & 72,444 & KeyCorp & US & 14,684 \\
\hline HBOS (until 13-10-2008) * & GB & 64,945 & Sampo & DK & 10,932 \\
\hline Merrill Lynch (until 05-12-2008) * & US & 66,887 & Anglo Irish Bank (until 15-01-2009) & IE & 11,146 \\
\hline Société Générale ** & $\mathrm{FR}$ & 66,752 & EFG Eurobank Ergasias & GR & 10,939 \\
\hline Deutsche Bank ** & $\mathrm{DE}$ & 60,014 & Deutsche Postbank & $\mathrm{DE}$ & 11,664 \\
\hline US Bancorp & US & 55,728 & Banco de Sabadell & $\mathrm{ES}$ & 10,662 \\
\hline Lloyds $* *$ & GB & 53,885 & M\&T Bank & US & 12,997 \\
\hline Crédit Agricole ** & $\mathrm{FR}$ & 56,026 & Banco Comercial Português (until 07-06-2012) & $\mathrm{PT}$ & 10,362 \\
\hline ABN Amro (until 25-04-2008) * & NL & 53,690 & Crédit Industriel et Commercial & FR & 8,434 \\
\hline Fannie Mae (until 07-09-2008) * & US & 49,789 & Northern Trust & US & 12,424 \\
\hline Fortis (until 04-10-2008) * & $\mathrm{BE}$ & 47,502 & Alpha Bank & GR & 9,891 \\
\hline Freddie Mac (until 07-09-2008) * & US & 42,093 & Marshall \& Ilsley (until 16-12-2010) & US & 11,622 \\
\hline Intesa Sanpaolo & IT & 34,931 & Sovereign Bancorp (until 13-10-2008) & US & 8,019 \\
\hline KBC & $\mathrm{BE}$ & 39,514 & CIT Group (until 24-07-2009) & US & 10,477 \\
\hline Metlife & US & 39,555 & Banco Popolare & IT & 10,453 \\
\hline Washington Mutual (until 26-09-2008) * & US & 44,656 & Landesbank Berlin & $\mathrm{DE}$ & 5,620 \\
\hline Prudential Financial & US & 38,056 & Eurohypo (until 25-07-2008) & $\mathrm{DE}$ & 10,039 \\
\hline Lehman Brothers (until 15-09-2008) * & US & 36,152 & Synovus Financial & US & 8,588 \\
\hline Standard Chartered (until 21-06-2011) ** & GB & 32,622 & Alliance \& Leicester (until 13-10-2008) & GB & 10,126 \\
\hline Nordea $* *$ & $\mathrm{SE}$ & 32,997 & Northern Rock (until 18-02-2008) & GB & 8,125 \\
\hline Natixis & FR & 12,458 & UBI Banca & IT & 8,744 \\
\hline Dexia (until 09-10-2011) ** & $\mathrm{BE}$ & 26,685 & Comerica & US & 9,025 \\
\hline Danske Bank & DK & 24,386 & Banco Espirito Santo & $\mathrm{PT}$ & 6,994 \\
\hline SunTrust & US & 27,858 & Zions Bancorporation & US & 8,738 \\
\hline Bank of New York Mellon ** & US & 25,548 & Piraeus Bank & GR & 6,099 \\
\hline Regions Financial & US & 15,649 & Kaupthing (until 06-10-2008) & IS & 7,294 \\
\hline Countrywide Financial (until 11-01-2008) * & US & 24,007 & Swiss Life & $\mathrm{CH}$ & 7,731 \\
\hline Allied Irish Banks (until 29-09-2010)* & $\mathrm{IE}$ & 21,084 & Hypo Real Estate (until 06-10-2008) & $\mathrm{DE}$ & 8,695 \\
\hline Commerzbank ** & $\mathrm{DE}$ & 24,374 & Hudson City Bancorp & US & 8,094 \\
\hline Charles Schwab & US & 21,654 & Compass Bancshares (until 15-02-2007) & US & 7,240 \\
\hline Erste Group & AT & 17,709 & Banca Popolare di Milano & IT & 5,189 \\
\hline $\mathrm{BB} \& \mathrm{~T}$ & US & 22,663 & Commerce Bancorp (until 01-10-2007) & US & 7,432 \\
\hline Capital One & US & 25,313 & People's United Financial & US & 4,571 \\
\hline National City (until 23-10-2008) * & US & 22,838 & Bankinter & $\mathrm{ES}$ & 5,195 \\
\hline
\end{tabular}

Note: * indicates banks identified as G-SIB (as explained in the main text), ** indicates banks identified as G-SIB by the Financial Stability Board. Market values are measured at the start of the sample and are expressed in millions of U.S. dollars. 
a G-SIB's default, they not only reflect default risk but also the recovery value of the G-SIB's assets, the market price of risk, and the probability that the writer of the CDS contract defaults himself. Still, CDS spreads have the advantage that they are directly observed in financial markets, and are widely used as indicators of default risk by practitioners, policy makers and academics alike.7 As an alternative indicator of G-SIBs' default risk, we use weekly changes in 5-year expected default frequencies (EDFs) as calculated by Moody's KMV. EDFs can directly be interpreted as default probabilities, as they are constructed by mapping a bank's distance-to-default to an empirical distribution of historical default events. Moody's calculates this distance-to-default using a proprietary method based on the Merton (1974) model, which incorporates variables such as the volatility and market value of equity and the book value of debt. Just as CDS spreads, EDFs are well-known indicators of default risk, but are not directly observed in financial markets. ${ }^{8}$

\section{Results}

\subsection{Trends}

Figure 1 shows the development of the average of all banks' market values, as well as the development of the averages of the G-SIBs' CDS spreads and EDFs. The first graph illustrates how the average of banks' market values fell by more than 75 percent over the 2007-2009 period. While market values started to recover by the end of 2009 , this recovery came to a halt in the beginning of 2010 when developments in Greece fueled fears about a European sovereign debt crisis. In 2011, bank market values recovered somewhat, but after a marked decline in 2012 they are still over 30 percent lower at the end of the sample period than at the start in 2007 .

The lower two graphs in Figure 1 show that G-SIB CDS spreads and EDFs increased substantially since the start of the crisis. As expected, default risk increases when stock prices decline. This visual resemblance between the graphs is confirmed by the correlation between the underlying time series, which equals -0.82 between market values and CDS spreads, and -0.75 between market values and EDFs.

\footnotetext{
${ }^{7}$ For some G-SIBs, CDS spreads are not available. This is the case for Bank of New York Mellon, Countrywide Financial, National City, and State Street. For Barclays, CDS spreads are available until 30 September 2010. The CDS spread for Lehman Brothers is obtained from Markit.

${ }^{8}$ EDFs are available for all G-SIBs except Bank of New York Mellon.
} 
Figure 1: Bank stock market values and default risk indicators Market value (average over all banks; USD)

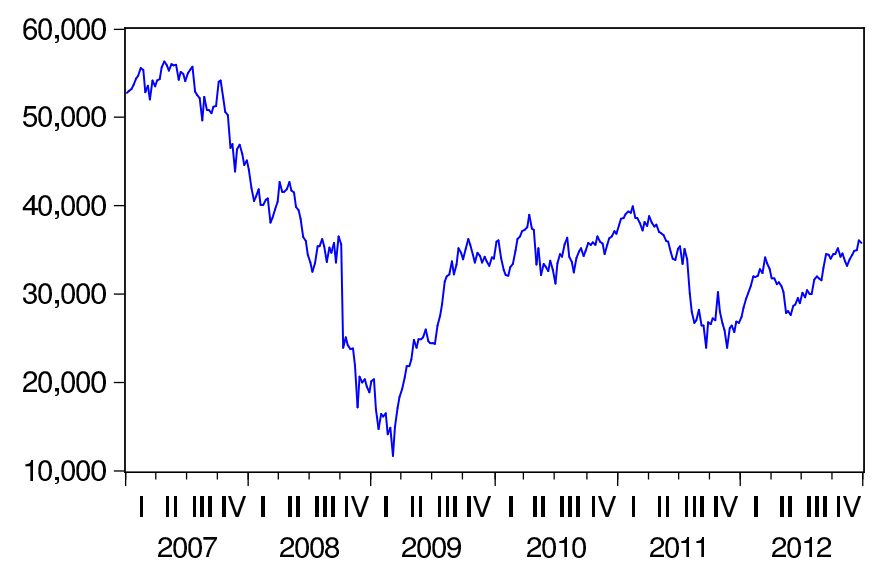

Credit default swap spread (average over G-SIBs; bp.)

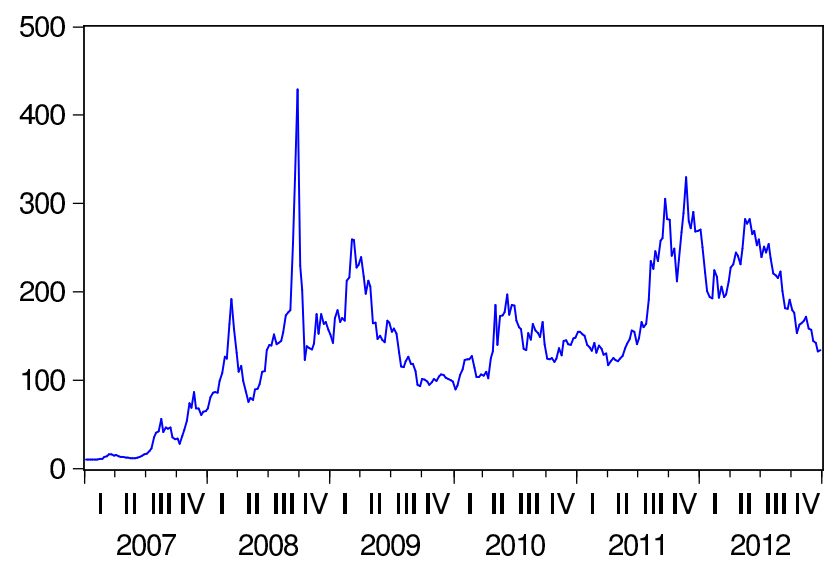

Expected default frequency (average over G-SIBs; \%)

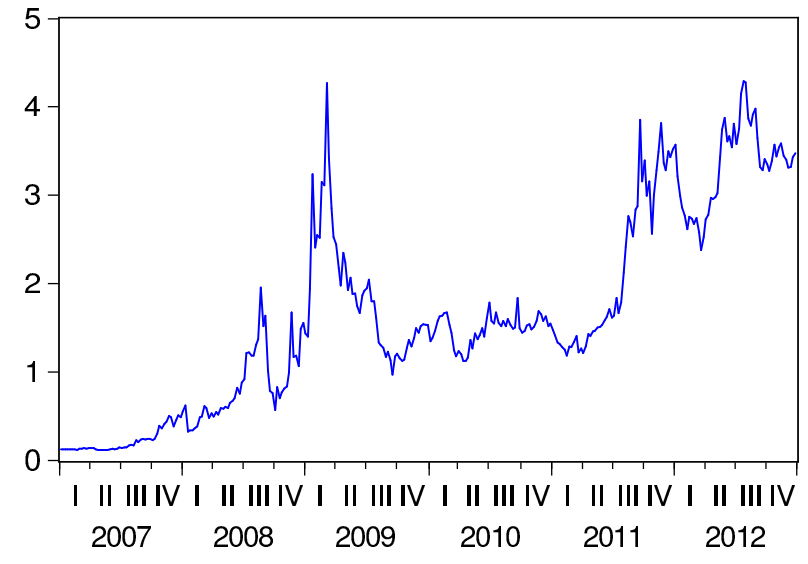




\subsection{Main results}

The top panel in Table 2 reports the results from estimating the regression model in Equation 1. To facilitate interpretation of the results, the $\beta$ and $\gamma$ coefficients were multiplied by the standard deviation of the corresponding regressor and divided by the standard deviation of the dependent variable. As a result, the coefficients in the table indicate the correlation between the dependent variable and the regressor.

Block (1) of the top panel in Table 2 presents the estimation results for the main regression. The first two columns present the estimates for the bank-fixed effects $\alpha_{n}$, which, except for five percent of the cross-sections, are indistinguishable from zero at the five percent significance level.

The next three columns present the results for the market factor. The cross-sectional average of the $\beta_{n}$ coefficients is economically large with a value of 0.37 , while the individual coefficient estimates are significantly positive for 95 percent of the banks in the cross-section. These results illustrate that bank market value changes exhibit a substantial common component. This component explains about 14 percent of the total variation in the dependent variable, as can be calculated by subtracting the $R^{2}$ of the first-step regression (which only includes the default risk variables) from the $R^{2}$ of the full specification estimated in the third step.

The entries in the next three columns focus on the spillover coefficients $\gamma_{m}$, which indicate to what extent changes in G-SIBs' default risk have an impact on other banks' market values. For individual G-SIBs this impact seems to be very limited. While the coefficients are statistically significant in 61 percent of the cross-sections, their economic magnitude is close to zero with a cross-sectional average of -0.04 . These individual coefficient estimates are presented in the panel on the left in Figure 2, with the horizontal axis ranking the G-SIBs according to size (e.g. 1 indicates Citigroup, the largest G-SIB in the sample). The panel on the right presents the same information in a box plot. Both figures illustrate that there are no exceptionally large or small coefficient estimates. Also, many of the estimates have a positive sign, in contrast to what would be expected.

Despite the near zero estimates for the spillover coefficients, $F$-test results confirm that in both the first and the third step of the estimation procedure, the spillover coefficients 
Table 2: Regression results

Regression equation: $y_{n t}=\alpha_{n}+\beta_{n} f_{t}+\sum_{m \neq n} \gamma_{m} p_{m t}+\epsilon_{n t}$;

\begin{tabular}{|c|c|c|c|c|c|c|c|c|c|c|}
\hline & \multicolumn{5}{|c|}{ Fixed effects and market factor } & \multicolumn{3}{|c|}{ Default risk (CDS) } & \multicolumn{2}{|c|}{ Overall } \\
\hline & $\alpha_{n}$ & $\alpha_{n} \neq 0$ & $\beta_{n}$ & $\beta_{n}>0$ & $R^{2}$ & $\gamma_{m}$ & $\gamma_{m}<0$ & $R^{2}$ & $R^{2}$ & $N$ \\
\hline (1) Full sample & 0.00 & $5 \%$ & 0.37 & $95 \%$ & 0.14 & -0.04 & $61 \%$ & 0.23 & 0.37 & 25,901 \\
\hline (2) Sub-samples based on location & & & & & & & & & & \\
\hline$n$ and $m$ from US & -0.01 & $12 \%$ & 0.43 & $95 \%$ & 0.16 & -0.05 & $61 \%$ & 0.34 & 0.50 & 9,687 \\
\hline$n$ and $m$ from $\mathrm{EU}$ & 0.01 & $7 \%$ & 0.43 & $97 \%$ & 0.20 & -0.03 & $51 \%$ & 0.22 & 0.42 & 16,214 \\
\hline (3) Sub-samples based on type & & & & & & & & & & \\
\hline$n$ systemically important & 0.01 & $6 \%$ & 0.38 & $94 \%$ & 0.16 & -0.04 & $60 \%$ & 0.29 & 0.45 & 12,972 \\
\hline$n$ not systemically important & -0.01 & $4 \%$ & 0.36 & $98 \%$ & 0.13 & -0.03 & $56 \%$ & 0.19 & 0.32 & 12,929 \\
\hline (4) Sub-samples based on time & & & & & & & & & & \\
\hline$t$ before Lehman default & 0.01 & $6 \%$ & 0.25 & $83 \%$ & 0.07 & -0.03 & $50 \%$ & 0.25 & 0.31 & 8,644 \\
\hline$t$ after Lehman default & 0.00 & $3 \%$ & 0.30 & $92 \%$ & 0.11 & -0.04 & $58 \%$ & 0.31 & 0.42 & 17,253 \\
\hline (5) Sub-samples based on risk & & & & & & & & & & \\
\hline$p$ larger than 75 th percentile & 0.22 & $82 \%$ & 0.44 & $95 \%$ & 0.20 & -0.04 & $53 \%$ & 0.17 & 0.38 & 25,901 \\
\hline$p$ smaller than 25 th percentile & -0.30 & $96 \%$ & 0.49 & $97 \%$ & 0.26 & -0.04 & $53 \%$ & 0.13 & 0.38 & 25,901 \\
\hline
\end{tabular}

\begin{tabular}{|c|c|c|c|c|c|c|c|c|c|c|}
\hline & \multicolumn{5}{|c|}{ Fixed effects and market factor } & \multicolumn{3}{|c|}{ Default risk (EDF) } & \multicolumn{2}{|c|}{ Overall } \\
\hline & $\alpha_{n}$ & $\alpha_{n} \neq 0$ & $\beta_{n}$ & $\beta_{n}>0$ & $R^{2}$ & $\gamma_{m}$ & $\gamma_{m}<0$ & $R^{2}$ & $R^{2}$ & $N$ \\
\hline (1) Full sample & -0.04 & $8 \%$ & 0.40 & $96 \%$ & 0.16 & -0.03 & $45 \%$ & 0.21 & 0.38 & 25,901 \\
\hline (2) Sub-samples based on location & & & & & & & & & & \\
\hline$n$ and $m$ from US & -0.05 & $10 \%$ & 0.49 & $100 \%$ & 0.24 & -0.03 & $37 \%$ & 0.27 & 0.51 & 9,687 \\
\hline$n$ and $m$ from EU & -0.03 & $5 \%$ & 0.47 & $97 \%$ & 0.24 & -0.02 & $59 \%$ & 0.19 & 0.43 & 16,214 \\
\hline (3) Sub-samples based on type & & & & & & & & & & \\
\hline$n$ systemically important & -0.04 & $12 \%$ & 0.41 & $94 \%$ & 0.18 & -0.03 & $36 \%$ & 0.27 & 0.45 & 12,972 \\
\hline$n$ not systemically important & -0.06 & $4 \%$ & 0.48 & $98 \%$ & 0.23 & -0.03 & $37 \%$ & 0.11 & 0.33 & 12,929 \\
\hline (4) Sub-samples based on time & & & & & & & & & & \\
\hline$t$ before Lehman default & -0.07 & $12 \%$ & 0.36 & $95 \%$ & 0.13 & -0.01 & $26 \%$ & 0.19 & 0.32 & 8,644 \\
\hline$t$ after Lehman default & -0.02 & $3 \%$ & 0.32 & $91 \%$ & 0.13 & -0.01 & $38 \%$ & 0.29 & 0.42 & 17,253 \\
\hline (5) Sub-samples bc & & & & & & & & & & \\
\hline$p$ larger than 75 th percentile & 0.16 & $79 \%$ & 0.44 & $96 \%$ & 0.21 & -0.03 & $39 \%$ & 0.17 & 0.38 & 25,901 \\
\hline$p$ smaller than 25 th percentile & -0.24 & $93 \%$ & 0.49 & $96 \%$ & 0.26 & -0.02 & $33 \%$ & 0.13 & 0.39 & 25,901 \\
\hline
\end{tabular}

Note: each coefficient has been standardised and thus reflects the correlation between the dependent and the corresponding independent variable. Percentages indicate the fraction of coefficients statistically significant at the 5 percent level. 
Figure 2: Spillover coefficients for individual G-SIBs
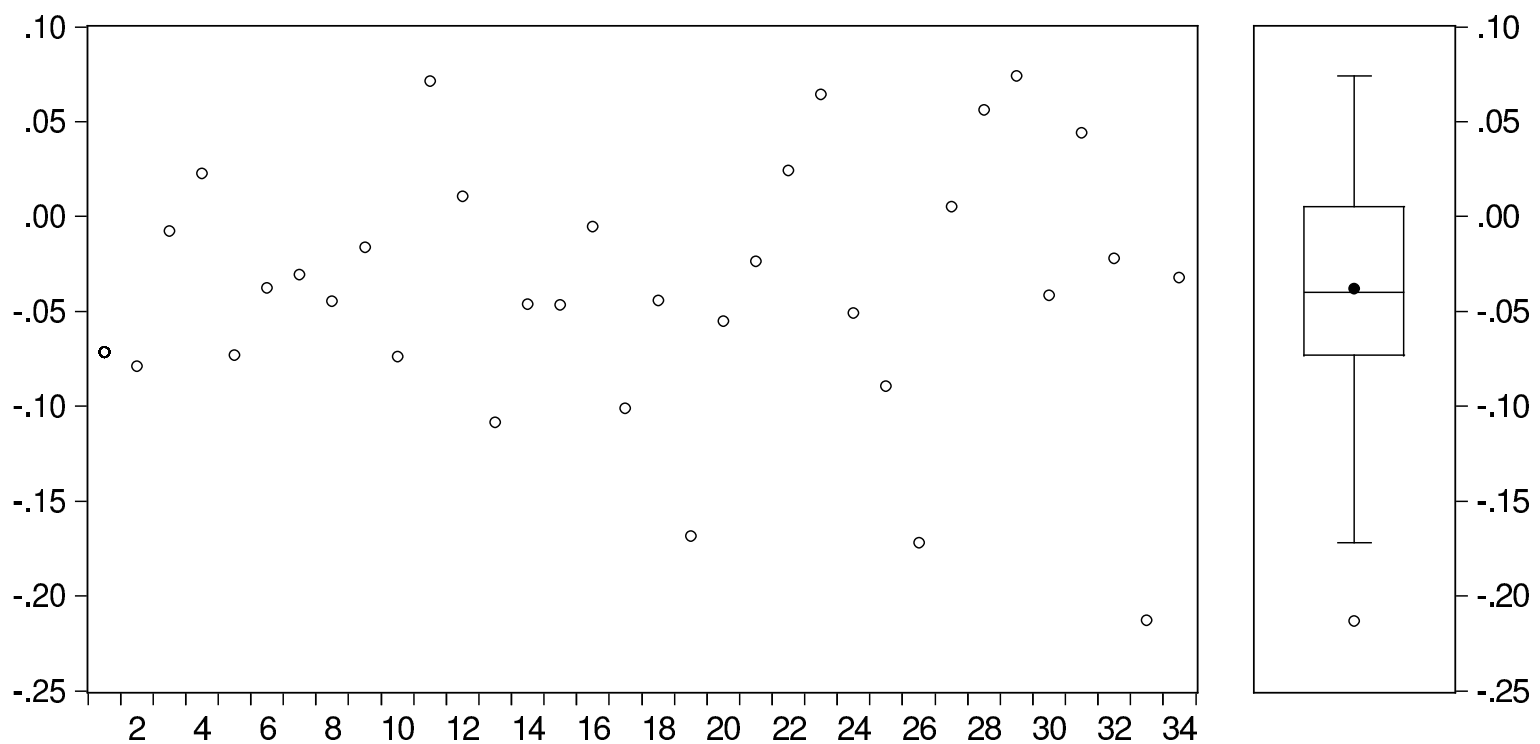

are jointly significant by a large margin $9^{9}$ Indeed, the eighth column in Table 2 reports the $R^{2}$ from the first-step regression, which shows that taken together, changes in bank default probabilities explain about 23 percent of changes in bank market values. 10

The entries in the final two columns in Table 2 report the overall model fit and the number of observations in the regression. They show that the model explains 37 percent of the variation in banks' market value changes, and that the estimates are based on a sample of more than 25,000 bank-week observations.

\subsection{Sensitivity analysis}

We test the robustness of our results using several alternative regression specifications. Block (2) in Table 2 shows the coefficient estimates obtained when the model is estimated for U.S. banks and EU banks separately. The coefficient of the common factor in both regions is larger than in the full sample estimates as reported in the first row, equaling 0.43 for both the US

\footnotetext{
${ }^{9}$ The test statistic $F=\frac{\left(R_{U}^{2}-R_{R}^{2}\right) /\left(k_{U}-k_{R}\right)}{\left(1-R_{U}^{2}\right) /\left(N-k_{U}\right)}$ follows an $F$-distribution with $\left(k_{U}-k_{R}, N-k_{U}\right)$ degrees of freedom, where subscripts $U$ and $R$ indicate the unrestricted and restricted model and $k$ indicates the number of model coefficients. For the first estimation step the statistic equals $\frac{(0.23-0) /(134-100)}{(1-0.23) /(25901-134)}=226.37$ while for the third step it equals $\frac{(0.37-0.14) /(234-200)}{(1-0.23) /(25901-234)}=225.49$. Both values are highly significant.

${ }^{10}$ Part of this explanatory power is due to those coefficients in Figure 2 that are positive, which may reflect banks' gains from the failure of a competitor. The coefficients estimate the net impact of spillovers and competition effects, which from a financial stability perspective is arguably the most important.
} 
and the EU. This finding seems plausible as banks from the same region are more exposed to the same type of shocks. At the same time, the spillover coefficients in both regressions are again nearly equal to zero, although they are statistically significant for most G-SIBs. The explanatory power of both models is higher than the explanatory power of the full sample regression.

In block (3) of the top panel in Table 2, we examine whether the coefficient estimates change when we include changes in the market values of only G-SIBs or of only non-G-SIBs as the dependent variable. As G-SIBs are relatively large and globally active, we might expect that their market values are more strongly correlated with the market factor. The table shows that the importance of this factor indeed differs across both sub-samples, but that the difference is economically negligible. Again, the spillover effects remain economically indistinguishable from zero. The explanatory power of the model is higher for the G-SIB sub-sample, while for the non-G-SIBs it is somewhat lower than the full sample equivalent.

Block (4) splits the sample in a pre- and a post-Lehman period. We expect spillover effects to be stronger after the Lehman default, as this event signaled to market participants that governments would not necessarily shield other banks from losses if a large bank were to go bankrupt. The results show that the coefficient of the market factor is somewhat smaller in the pre-Lehman sample than during the period thereafter, while the coefficients of the default risk variables are virtually the same across both periods. As before, these spillover coefficients are significant but nearly equal to zero. The joint explanatory power of the changes in G-SIB default risk is higher for the post-Lehman period than for the full-sample period, and so is the overall model fit.

Block (5) separately examines the impact on market values of large increases and large decreases in G-SIB default risk. It could be that bank market values respond only to larger changes in default risk, or respond differently to increases or decreases therein. The results provide no evidence for such effects, however, as the average of the spillover coefficients is constant across both specifications and equal to its full-sample value 11

Finally, we run the same regressions using EDFs rather than CDS-spreads as indicators of G-SIBs' default risk. The bottom panel of Table 2 presents the results. Despite the conceptual

\footnotetext{
${ }^{11}$ The fixed effects in the first column now pick up the variation in market value changes that would otherwise have been explained by the omitted fluctuations in G-SIBs' default risk. The second row, for instance, illustrates that replacing the 75 percent largest increases in each G-SIB's default risk by zeros leads the fixed effects to become negative, reflecting the omitted default risk increases' negative impact on bank market values.
} 
and empirical differences between both indicators, the results for the EDF regressions are essentially the same as those for the CDS spreads regressions. The main difference is that in the EDF regressions the coefficients of the market factor are somewhat larger, while the joint explanatory power of the spillover coefficients is somewhat smaller 12

\subsection{Discussion}

While the coincidence of instability between banks has often been analysed in the economic literature (see, for instance, Adrian and Brunnermeier 2011, Acharya, Pedersen, Philippon, and Richardson 2012), Helwege (2010) discusses that this coincidence can be due to spillover effects as well as to common shocks affecting banks with similar balance sheets ${ }^{13}$ Our analysis shows that bank market values are indeed substantially driven by such common shocks, as indicated by the economically and statistically significant $\beta$ coefficients for the market factor. Examples of developments captured by this factor are changes in investor risk aversion, global economic developments, or bank regulation and bailout policies. In addition, our analysis shows that bank market values hardly respond to changes in the default risk of individual GSIBs, as indicated by the economically small $\gamma$ coefficients. Bank market values do respond, however, to the combination of changes in the default risk of individual G-SIBs. This is indicated by the joint significance of the $\gamma$ coefficients and their combined explanatory power.

To interpret the last two findings, we distinguish between spillovers stemming from tooimportant-to-fail and from too-many-to-fail effects. The first effect arises if an individual G-SIB is so systemically important that an increase in its default risk or its actual default can destabilise the financial system at large. Our results do not provide strong evidence for such effects. The second effect arises if G-SIBs are systemically important as a group, implying that a simultaneous increase in their default risk or their simultaneous default has a destabilising impact on the system. Our analysis suggests that G-SIBs are indeed systemic as a group, as the combination of changes in their individual default risk explains a substantial part of changes in bank market values.

\footnotetext{
${ }^{12}$ The stability and statistical significance of the spillover effects across regression specifications also mitigates potential concerns about collinearity of the default risk variables, even though collinearity would only affect the statistical significance of the coefficient estimates and not their economic magnitude.

${ }^{13}$ See Acharya and Yorulmazer (2007) and Wagner $(2008,2010)$ for theoretical analyses of banks' vulnerability to common shocks, and Aharony and Swary (1983), Calomiris and Mason (1997), Mink and de Haan (2013), and Helwege and Zhang (2013) for empirical evidence.
} 
Some caveats are in order. First, we may overestimate spillover coefficients by allowing them to pick up variation in market values that should actually be attributed to the market factor. An example of this effect would be a sudden policy change that limits government support for financial institutions 14 Such a policy change drives down bank market values, but simultaneously pushes up G-SIBs' default risk. This effect is therefore picked up by the default risk changes $p_{m t}$ in the first regression step, instead of being attributed to the market factor in the second step. As a result, the final regression step understates the role of the market factor while overestimating the role of spillover effects. However, only the conclusions on spillovers from the group of G-SIBs could be sensitive to this issue, as spillovers from individual G-SIBs are found to be minor.

Second, we may underestimate spillover effects because of governments' interventions and rescue operations during the crisis. In general, however, such interventions are designed to shield investors in bank debt from losses, but not investors in bank equity (see also King 2009). As we focus on the impact of spillover effects on bank equity values, such interventions have only limited potential to bias our results. In addition, many government interventions aim to avoid G-SIB defaults. Such interventions dampen fluctuations in G-SIBs' default risk, but do not affect our estimates for the impact of the remaining fluctuations on other banks' market values.

Third, our analysis is based on financial market data so that our results are conditional on the accuracy of market participants' expectations. Hence, if financial markets would underestimate or overestimate the spillover effects of a G-SIB's potential default, our spillover estimates will be biased as well. Either way, however, our estimates indicate to what extent market participants' concerns for such spillover effects contributed to the decline in bank market values during the financial crisis, and, therefore, to what extent alleviating these concerns could have stabilised bank market values.

\footnotetext{
${ }^{14}$ For instance, Huertas (2010), at the time vice-chairman of the Committee of European Banking Supervisors, argues that: "What the failure of Lehmans did do was to underline to market participants that the U.S. government would not necessarily stand behind other broker dealers. [...] It led to an immediate re-pricing of risk, to a flight to quality and to a run away from institutions judged most likely to require intervention." In this view, the Lehman Brothers collapse revealed to investors that the U.S. government will not by definition support large financial institutions, which can have a substantial impact on such institutions' value and stability (see, for instance, Dam and Koetter 2013).
} 


\section{Conclusion}

Financial crisis management and prevention policies often focus on mitigating spillovers from the default of systemic banks. During the crisis, governments avoided large bank failures by insuring and purchasing intermediaries' troubled assets, by providing them with capital injections, and even by outright nationalisations. After the crisis, financial regulators tried to identify those banks that are too-important-to-fail, and designed additional requirements for such globally systemically important banks (G-SIBs).

We analyze individual banks' systemicness by examining to what extent changes in bank market values during the 2007-2012 financial crisis were due to the changes in G-SIBs' default risk. If financial markets expect a G-SIB's default to cause losses for other banks, an increase in their assessment of this G-SIB's default probability should lead to a decline in other banks' market values. Our regression analysis shows that the market values of the one hundred largest banks in the United States and the European Union hardly respond to changes in individual G-SIBs' default risk. Together, however, changes in G-SIBs' default risk explain a substantial part of bank market value changes. This result suggests that G-SIBs are systemically important as a group.

Our results do not imply that during the crisis individual G-SIBs could have been allowed to go bankrupt without consequences for the stability of the financial system. While spillovers caused by such failures may be smaller than feared, financial market participants generally assumed that governments would stand ready to rescue any failing G-SIBs. Suddenly reverting such a policy would act as an adverse common shock driving up investors' assessment of default risk for the G-SIBs as a group. Our results show that such a joint increase in G-SIBs' default risk would depress other banks' market values. Dynamics such as these are likely to have played an important role in the aftermath of the Lehman Brothers collapse in September 2008.

While bailing out individual G-SIBs during the recent crisis may thus have been inevitable, our finding that spillovers from individual G-SIBs are relatively limited suggests that governments should in the future be able to commit more credibly to not bailing out individual G-SIBs. The actual failure of a G-SIB would then be less of a shock to financial markets. Our results also imply that future declines in bank market values may be mitigated by increasing the resilience of banks to spillovers from G-SIBs as a group and to adverse common shocks. 


\section{Acknowledgements}

The authors thank Jack Bekooij, Caitlin Briglio and Leo Kranenburg for their assistance in constructing the dataset, and appreciates valuable comments and suggestions by our discussants Gary Gorton, Nadia Massoud and Tom Wansbeek, and by Jaap Bikker, Dirk Broeders, Hans Degryse, Stijn Ferrari, Renée Fry, Melissa Hamilton, Diana Hancock, Niels Hermes, Skander van den Heuvel, Neeltje van Horen, Jan Jacobs, Iman van Lelyveld, Ralf Meisenzahl, Joost Passenier, Enrico Perotti, Rodney Ramcharan, Larry Wall, and participants in the DNB Lunch Seminar Series, the SOM Seminar of 3 June 2010, the Norges Bank Financial Stability Conference of 2-3 September 2010, the Basel Committee on Banking Supervision Workshop on Applied Banking Research of 26-27 May 2011, the Federal Reserve Board Financial Studies Lunch Seminar of 4 December 2012, the Humboldt-Copenhagen Conference on Financial Econometrics of 14-16 March 2013, and the Federal Reserve System "Day-Ahead" Conference on Financial Markets and Institutions of 2 January 2014. Any remaining errors are those of the authors. The views expressed in this paper do not necessarily reflect those of De Nederlandsche Bank. 


\section{References}

Acharya, V., L. Pedersen, T. Philippon, and M. Richardson (2012): "Measuring systemic risk," Working Paper No. 8824, CEPR, London, UK.

Acharya, V., and T. Yorulmazer (2007): "Too Many to Fail - An Analysis of Timeinconsistency in Bank Closure Policies," Journal of Financial Intermediation, 16, 1-31.

Adrian, T., And M. Brunnermeier (2011): "CoVaR," Working Paper No. 17454, NBER, Cambridge, MA.

Aharony, J., And I. Swary (1983): "Contagion Effects of Bank Failures: Evidence from Capital Markets," Journal of Business, 56, 305-22.

Allen, F., And D. Gale (2000): "Financial Contagion," Journal of Political Economy, 108, $1-33$.

Basel Committee on BAnking Supervision (2011): Global systemically important banks: assessment methodology and the additional loss absorbency requirement. Bank for International Settlements, Basel, Switzerland.

Brewer III, E., H. Genay, W. Hunter, and G. Kaufman (2003): "Does the Japanese Stock Market Price Bank-Risk? Evidence from Financial Firm Failures," Journal of Money, Credit and Banking, 35, 507-43.

Brewer III, E., And J. Jagtiani (2013): "How much Did Banks Pay to Become Too-BigTo-Fail and to Become Systemically Important?," Journal of Financial Services Research, $43,1-35$.

Calomiris, C., and J. Mason (1997): "Contagion and Bank Failures During the Great Depression: The June 1932 Chicago Banking Panic," American Economic Review, 87, 863-83.

Chen, Y. (1999): "Banking Panics: The Role of First-Come, First-Served Rules and Information Externalities," Journal of Political Economy, 107, 946-68.

Dam, L., And M. Koetter (2013): "Bank bailouts and moral hazard: evidence from Germany," The Review of Financial Studies, 25, 2343-80. 
De Bandt, O., P. Hartmann, and J. Peydró (2010): "Systemic Risk in Banking: an update," in The Oxford Handbook of Banking, ed. by M. P. Berger, A.N., and J. Wilson, pp. 633-72. Oxford University Press, Oxford, UK.

Financial Stability Board (2010): "Reducing the moral hazard posed by systemically important financial institutions," Report to G20 leaders, 18 June 2010.

- (2011): "Policy measures to address systemically important financial institutions," Press release, 4 November 2011.

Freixas, X., B. Parigi, and J. Rochet (2000): "Systemic Risk, Interbank Relations, and Liquidity Provision by the Central Bank," Journal of Money, Credit and Banking, 32, $611-38$.

HeLwege, J. (2010): "Financial firm bankruptcy and systemic risk," Journal of International Financial Markets, Institutions \& Money, 20, 1-12.

Helwege, J., And G. Zhang (2013): "Financial firm bankruptcy and contagion," Working paper.

Huertas, T. (2010): "The Road to Better Resolution: From Bail-Out to Bail-In," Speech delivered at the Bank of Slovakia Conference on The Euro and the Financial Crisis, Bratislava, Slovakia.

Jorion, P., And G. Zhang (2009): "Credit contagion from counterparty risk," The Journal of Finance, 64, 2053-87.

Kaufman, G. (1994): "Bank contagion: a review of the theory and evidence," Journal of Financial Services Research, 8, 123-50.

Kho, B., D. Lee, and R. Stulz (2000): "US Banks, Crises and Bailouts: From Mexico to LTCM," American Economic Review, 90, 28-31.

KING, M. (2009): "Time to buy or just buying time? The market reaction to bank rescue packages," Working Paper No. 288, Bank for International Settlements, Basel, Switzerland.

Merton, R. (1974): "On the Pricing of Corporate Debt: The Risk Structure of Interest Rates," Journal of Finance, 29, 449-70. 
Mink, M., And J. DE HAAn (2013): "Contagion during the Greek sovereign debt crisis," Journal of International Money and Finance, 34, 102-13.

ShleIfer, A., AND R. Vishny (1992): "Liquidation values and debt capacity: a market equilibrium approach," Journal of Finance, 47, 1343-66.

(2011): "Fire sales in finance and macroeconomics," Journal of Economic Perspectives, 25, 29-48.

Special Inspector General for the Troubled Asset Relief Program (2011): Extraordinary Financial Assistance Provided to Citigroup, Inc. Office of the Inspector General, Washington, DC.

Wagner, W. (2008): "The Homogenization of the Financial System and Financial Crises," Journal of Financial Intermediation, 17, 330-56.

_ (2010): "Diversification at Financial Institutions and Systemic Crises," Journal of Financial Intermediation, 19, 373-86. 